\title{
Aandelen zonder stemrecht
}

Citation for published version (APA):

Schwarz, C. A. (1990). Aandelen zonder stemrecht. W.E.J. Tjeenk Willink. https://doi.org/10.26481/spe.19900126cs

Document status and date:

Published: 26/01/1990

DOI:

10.26481/spe.19900126cs

Document Version:

Publisher's PDF, also known as Version of record

\section{Please check the document version of this publication:}

- A submitted manuscript is the version of the article upon submission and before peer-review. There can be important differences between the submitted version and the official published version of record.

People interested in the research are advised to contact the author for the final version of the publication, or visit the DOI to the publisher's website.

- The final author version and the galley proof are versions of the publication after peer review.

- The final published version features the final layout of the paper including the volume, issue and page numbers.

Link to publication

\footnotetext{
General rights rights.

- You may freely distribute the URL identifying the publication in the public portal. please follow below link for the End User Agreement:

www.umlib.nl/taverne-license

Take down policy

If you believe that this document breaches copyright please contact us at:

repository@maastrichtuniversity.nl

providing details and we will investigate your claim.
}

Copyright and moral rights for the publications made accessible in the public portal are retained by the authors and/or other copyright owners and it is a condition of accessing publications that users recognise and abide by the legal requirements associated with these

- Users may download and print one copy of any publication from the public portal for the purpose of private study or research.

- You may not further distribute the material or use it for any profit-making activity or commercial gain

If the publication is distributed under the terms of Article $25 \mathrm{fa}$ of the Dutch Copyright Act, indicated by the "Taverne" license above, 
AANDELEN ZONDER STEMRECHT 



\section{AANDELEN ZONDER STEMREGHT}

\section{REDE}

uitgesproken bij de aanvaarding van het ambt van gewoon hoogleraar in het recht, in het bijzonder in het handelsen ondernemingsrecht aan de Rijksuniversiteit Limburg, op vrijdag 26 januari 1990

door

MR. C. A. SCHWARZ

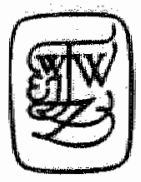

W.E.J. Tjeenk Willink Zwolle 1990 
Alle rechten voorbehouden. Niets uit deze uitgrive mag worden verveelwowdigd, opgeslagen in een geautomatiseerd gegevensbestand, of openbaar gemaakt, in enige vorm of op enige wijze, hetzij elektronisch, mechanisch, door fotokopieën, opnamen of enige andere manier, zonder voorafgaande schriftelijke toestemming van uitgeverij W.E.J. Tjeenk Willink te Zwolle.

Voor zover het maken van kopieèn uit deze tnitgave is toegestaan op grond van art. $16 \mathrm{~B}$ Auteurswet 1912 jo. het Besluit van 20 juni 1974, Stb. 351, zoals gewijzigd bij Besluit van 23 aug. 1985, Stb. 471 , en art. 17 Auteurswet 1912 , dient men de daarwoor wettelijk verschuldigde vergoedingen te voldoen aan de Stichting Reprorecht (Postbus 882, 1180 AW Amstelveen). Voor het overnemen van gedeelte( $n$ ) uit deze witgave in bloemlezingen, readers en andere compilatiewerken (art. 16 Auteurswet 1912) dient men aich tot de uitgever te wenden.

No part of this book may be reproduced in any form, by print, photoprint, microfilm or any other means without written permission from the publisher.

CIP-gegewens Koninklijke Bibliotheek, Den Hagg

Schwark, $\mathrm{C}$. A.

Aandelen zonder stemrecht / C. A. Schwarz - Zwolle:

W. E.J. Tjeenk Willink

Inaugurele rede Maastricht.

ISBN $90-271-3156-2$

BISO 345.7 UDC $336.763 .2(043.5)$ NUGI 692

Trefw: aandelen. 


\section{AANDELEN ZONDER STEMRECHT}

Mijne Heren Leden van het College van Bestuur,

Mijnheer de Rector Magnificus,

Dames en Heren leden van het weterschappelijk corps,

Dames en Heren leden van de niet-retenschappelijke staf,

Dames en Heren studenten,

en voorts Gij allen die mij door Uw aanwezigheid bij deze plechtigheid vereert, Zeer gewaardeerde toehoorders.

1. Nog meer dan juristen gaan economen uit van het slechte in de mens. Ook in dit kader is het verheugend dat wij sinds enige tijd een hoogleraar in de economische ethiek aan onze instelling verbonden weten. Een mooi voorbeeld van het somber uitgangspunt van economen wordt aangetroffen in de zogeheten 'Agency-theorie'. Toepassing van deze theorie binnen vennootschappelijke verhoudingen leidt, vanuit economisch perspectief, onder meer tot de conclusie dat managers van een grote onderneming hun macht gebruiken om eigen persoonlijke belangen als invloed, prestige en financieel gewin na te jagen, ongeacht de vraag of dit jagen ten koste gaat van de aandeelhouders. ${ }^{1}$ Deze situatie doet zich binnen de kapitaalvennootschap voor in het spanningsveld tussen bestuur en aandeelhouders. De mate van spanning is afhankelijk van de mate waarin bestuurders al dan niet vereenzelvigd kunnen worden met de kapitaalverschaffers, dus van de mate waarin er sprake is van bestuurlijke inbreng van de aandeelhouders. Duidelijk is dat van zodanige spanning geen sprake is bij een personele unie tussen bestuur en aandeelhouders, zoals die zich voordoet bij de éenmansvennootschap, waarin de enige aandeellhouder directeur is. Naarmate die bestuurlijke inbreng geringer wordt, neemt de spanning toe. Bij de zeer grote open NV zal die spanning het grootst zijn. Met het oog op laatstbedoelde verschijningsvorm verduidelijkt de econoom Rietkerk ${ }^{2}$ deze spanning door de verschillende belangen te definiëren.

1. S.W. Douma, Maandblad voor Accountancy en Bedrijfshuishoudkunde 61, No 11 (1987), p. 422. Zie ook G.W.J. Hendrikse en H. Schreuder, ESB 2-9-1987, p. 810 e.v. alsmede J.H.R. van de Poel, Als de tekenen bedriegen. . ., Woltersi-Noordhoff Groningen 1988 , p. 16 e.v.

2. G. Rietkerk, De NV 66/2 (1988), p. 46. 
Het belang van de aandeelhouder, die hier de positie van bellegger inneemt, is het maximaliseren van de waarde van de aandelen. Het belang van de bestuurder is een 20 hoog mogelijk inkomen bij een sub-maximale inspanning zonder zijn positie op de tocht te zetten. De één kapitalist, de ander een hebberig lijntrekker dus.

De wettelijke regeling van NV en BV onderkent dit mechanisme en verschaft een kader waarbinnen die spanning wordt gereguleerd. In de regeling word thet belang van de kapitaalverschaffer beschermd, onder meer door toekenning van belangrijke bevoegdheden aan het ledensubstraat van de vereniging van kapitaalverschaffers, de algemene vergadering van aandeelhouders. Belangrijkste bevoegdheden zijn wel die tot vaststelling van de jaarrekening in combinatie met de bevoegdheid tot benoeming, schorsing en ontslag van bestuurders. ${ }^{3}$

In het dualistisch systeem van de kapitaalvennootschap speelt de algemene vergadering een belangrijke sturende, alsook corrigerende rol. De aandeelhouders komen belangrijke bevoegdheden toe die van grote invloed kunnen zijn op het binnen de vennootschap gevoerde beleid. ${ }^{4}$ De vraag of de aandeelhouders ook gebruik van deze bevoegdheden maken is een andere.

In dit kader is het verhelderend om het belangenconflict tussen kapitaalverschafters en bestuur binnen de VOC geschetst te zien, zoals Van der Heijden dat in 1908 deed. ${ }^{5}$ De participatie ("actie") in de compagnie had in oorsprong een bloot vermogensrechtelijk karakter, totdat, onder druk van de kapitalverschaffers, in 1623 een verplichting voor de bewind hebbers werd gecreëerd tot het in het openbaar doen van rekening en verantwoording. Daarnaast werd een toezichthoudend college van negen hoofdparticipanten ingesteld, in welk college de contouren van de moderne Raad van Commissarissen kunnen worden

3. Deze bevoegdheder zijn onderdeel van het in de vennootschap functionerend inteme controle- en sturingssysteem en kunnen tot de "monitoring" gerekend worden. Zie Rietkerk, 1. a. p. noot $2, \mathrm{p} .47$. De bevoegd heidsverdeling ligt overigens anders binnen vennootschappen die aan de structuurregeling zijn onderworpen. Vgl. voor de NV de art. 2:152 e.v. $\mathbb{B}$ W en voor de BV de art. 2.262 e.w. BW.

4. Bimnen de strucruurvennootschap is de macht van de aandeelhouders veel beperkter en liggen cruciale bewoegdheden bij de Raad van Commissarissen. Hier dient vooral te wordem gedacht aan de bevoegdheid tot benoeming en ontslag van bestuurders. Zie art. 21162 en 272 BW. Ook binnen structuurvennootschappen blijven belangrijke bevoegdheden bij de algemene vergadering berusten. Te denker walt aar het aanbevelingsrecht en het bezwaarrecht bij benoening van commissarissen en aan het recht tot het goedkeuren van de jaarrekening. 5. E.J J van der Heijden, De ontwikkeling van de Naamlooze Vennootschap in Nederland wór de codificatic" "Gravenhage 1908, p. 62 e.w. Zie ook G.J. Boelems, Oligarchische clausules in statuter van Namimlooze Vennootschappen, Diss. Amsterdam 1946. 
herkend. ${ }^{6}$ Eveneens vond in die tijd de principiêle erkenning plaats van het recht van kapitaalverschaffers om invloed uit te mogen oefenen op de keuze van bewindhebbers.

Opvallend is vervolgens dat, ondanks deze medezeggenschapsregelingen, de VOC haar a ristocratisch karakter behield en de rechten van participanten met voeten trad, wat mogelijk was, nu aan de zijde van de participanten geen interesse bestond hun rechten ook uit te oefenen. Naar Van der Heijden wermoedt, hangt dit laatste verschijnsel samen met het feit dat het rendement op de inleg steeds méér dan bevredigend was. $^{\text {? }}$

2. Niets nieuws onder de zon. Al vele decennia wordt geklaagd over het gebrek aan vennootschappelijke betrokkenheid van (vooral kleine) aandeelhouders in publieke vennootschappen en het onbenut laten van de mogelijkheid over te gaan tot uitoefening van hun zeggenschapsrechten. Dit verschijnsel kan, gezien het door de wetgever beoogde machtsevenwicht bij de kapitaalvennootschap, als onwenselijk worden gekwalificeerd. Boelens heeft dit mooi geformuleerd. Na een schets van 'het nieuwe soort aandeelhouders', dat geen band met de ondernerning voelt, wier belangen niet met de onderneming samenvallen, die slechts geinteresseerd zijn in hoge koersen en vette dividenden, en die geen notie hebben van ondernemingsproblemen, merkt hij treffend op ${ }^{9}$ :

'Aan deze aandeelhouders, waartegenover zich een kleine groep steit, hoofdzakelijk uit groot-aandeelhouders bestaande, die nog behooren tot het oude soort en door Schmey ${ }^{10}$ als ondernemings-aandeelhouders

6. Overigers ontbrak en Rat van Commissarissen binnen de Code Commence; de franse wetgeving die ten grondslag ligt aan de thans vigerende wettelijke regeling van $N V$ en, indirect $B V$.

7. Aannemelik lijkt de werondersteling dat dit streven tot het koest houden van participanten in belangrijke mate heef bijgedragen tot het feit dat de VOC bij haar ophefling cen schuld bleek te hebben van zo" 134 miljoen guiden.

8. Vgl bijwoorbeeld J C. Brezet, De NV 1952, p. 192 e.v, o.m. verwijzende naar het bijna cen halve eeuw eerder verschenen werk van $R$, Passow, getiteld 'Die wirtschaftliche Bedeutwing und Organisation der Aktiengesellschaft, en W.C. Posthumus Meyjes, TVVS 1960. 1961 , p. 238 e.v., W.C.L. van der Grinten, De NV 1968, p. 187 e.v , en Boelens, \#, a woot 5, p. 12 c.v.

9. Boelens; t.a.p. noot 5 , p. 14 .

10. Boelens verwijst naar F.E. Schmey, Amerikaansche en Contunentale opvantingen omtrent het vraagstuk der NV, Openbare les, Haarlem 1935. 
worden betiteld, over levenskwesties van de onderneming als de vaststelling en bestemming van de winst, benoeming en ontslag van de directie, opheffing of fusie, de beslissing te laten, is zonderling".

Wat Boelens hier wil zeggen is dat het niet aangaat dat een toevallige meerderheid ter algemene vergadering, overigens een verhoudingsgewijs klein deel van het kapitaal vertegenwoordigend, besluiten kan nemen dile niet in het belang van de onderneming zijn en de stabiliteit van het vennootschappelijk beleid in gevaar brengen. In dit kader denke men dan vooral aan de positie van bestuurders die, althans in het gewone vennootschappelijk model, in principe te allen tijde kunnen worden geschorst of ontslagen.

Met dit argument, maar ook met andere, zoals bescherming tegen overvallen of bescherming van bepaalde belangenposities, wordt op grote schaal gebruik gemaakt van oligarchische regelingen.

3. Oligarchische regelingen kunnen worden gedefinieerd als al die bepalingen in de statuten van de vennootschap, die de strekking hebben de macht, die het wettelijk vennootschapsrecht de aandeelhouders toekent, bij de bestuurders van de vennootschap of een met hen nauw verbonden groep te brengen."

In het kader van dit college zou het te ver voeren alle regelingen met deze aard de revue te laten passeren. Een belangrijk gedeelte van deze regelingen voldoet, juist gezien de lage opkomstpercentages ter algemene vergadering, bijzonder goed. Men denke hier dan vooral aan quorumeisen die de wet stelt, bijvoorbeeld bij het besluit tot het ontnemen van het bindend karakter aan een voordracht bij bestuursbenoeming ${ }^{12}$, of die statutair worden aangelegd. ${ }^{13}$

In zijn algemeenheid kunnen de bevoegdheden van de algemene vergadering in hoge mate worden beperkt. Uiteraard kunnen alle niet-dwingendrechtelijke bevoegdheden die dle wet aan de algemene vergadering toekent haar statutair worden ontnomen, terwijl door

11. Definitie van $E$. Tekenbroek, De verhouding tusschen de aandeelhouders en de bestuurders bij de publieke naamlooze vennootschap in Nederland, Diss. Rotterdarn 1923, p. 68 .

12. Vigl. art. 2:133 lid 2 BW.

13. Vigl. R.P. Voogd, Statutaire beschermingsmiddelen bij beursvennootschappen, Diss. Nijmegen 1989, p. 41 e.v. 
statutaire regeling het effect van de wèl d wingendrechtelijk toegekende bevoegdheden sterk kan worden ingeperkt. Men denke aan een statutair vereiste waarin voor besluiten van de algemene vergadering goedkeuring door - of een voorstel van een zekere instantie wordt geëist. Terzijde merk ik op dat zo'n eis niet kan worden gesteld bij een besluit tot benoeming, schorsing of ontslag van bestuurders. Bij deze besluiten kan slechts gewerkt worden met een versterkte meerderheids- of quorumeis, eventueel in combinatie met de bepaling dat die eis niet gehanteerd word $t$ indien wordt besloten op voorstel van die instantie.

De bijzondere bevoegdheden in het kader van deze oligarchische regelingen worden statutair, zoals bekend, veelal toegekend aan een bijzondere categorie aandelen, vaak prioriteitsaandelen geheten.

Over de ratio van deze regelingen schreef Van der Grinten dichterlijk:

'Prioriteitsrechten zijn kinderen van de nood, van de angst, en van een streven naar machtsbehoud. Naar mijn indruk is de laatste factor - streven naar machtsbehoud - van afnemende betekenis (. . .). Nood en angst zijn de andere motieven. De nood van bestuurders en commissarissen, dat zij niet door de algemene vergadering waarvan zij de samenstelling niet in de hand hebben, zullen worden ontslagen. De angst dat door de algemene vergadering aan de zittende colleges onwelgevallige bestuurders en commissarissen zullen worden opgedrongen door uitoefening van het benoemingsrecht. ${ }^{14}$

Oligarchische regelingen verstoren, ongeacht de vraag of de oligarchische rechten al dan niet bij de door Van der Grinten bedoelde functionarissen berusten, het dualistisch systeem. Dit systeem zou, indien er een nauwere band tussen aandeelhouders en vennootschap zou bestaan, mijns inziens uitstekend kunnen functioneren.

Wanneer men zich realiseert dat oligarchische constructies tot doel hebben de macht van de algemene vergadering te beperken, terwijl het gebruik van deze regelingen, gezien het disfunctioneren van de algemene vergadering als vennootschappelijk orgaan binnen het dualistisch systeem, zeer in zwang is, kan de vraag worden opgeworpen of de huidige wettelijke regeling met betrekking tot de machtspositie van aandeelhouders bij de grote, publieke vennootschap, nog wel voldoet. ${ }^{15}$

14. W.C.L van der Grinten, De NV 1968, p. IB8.

15. Met Van der Grinten kan ingestemd worden war hij zich keert tegen een rigoureuze oplossing van het probleem door afschaffing wan de algemene vergadering. Zie de Verdambundel ('Uit het recht" 1971 ), p. 295 e.v. 
Deze problemen zouden kunnen worden weggenomen bij introductie van aandelen zonder stemrecht in ons vennootschapsrecht. Dat deze behoefte in de praktijk bestaat, is inmiddels duidelijk gebleken. ${ }^{15}$ Daarnaast zou door zodanige introductie aansluiting gevonden worden bij de ons omringende landen alsook bij de wettelijke regeling van andere EG-partners alsmede andere rechtssystemen. ${ }^{27}$

16. Deze behoefte kan in de praktijk leiden to allerhande gekunstelde constructies. Vgl. J.I.H.M. Galavazi en H. van Willsum, De NV 66/4 (1988), p. 130 e.w. Ook SHV maakte onlangs bekend behoefte te hebben an het scheppen van een participatiemogelijkheid zonder dat sterrirecht aan de kapitaalverschaffers wordt verleend. Zie de Volkskrant d.d. 7 november 1989. Ten onzent heeft de certificering van aandelen een hoge whucht genomen. Ook door certificering vindt feitelijk loskoppeling van vermogenswatade en zeggensmacht plartts, deels afhankelijk van het feit of deze certificaten al dan niet royeerbaar zijn.

17. Aandelen zonder stemrecht komen in zeer veel landen woor. België kent dit fenomeen reeds $\mathbb{t}$ a $w$. vennootschappen die in de textielsector werkzaam zijn, alsmede t.a.v. de zogenaamde reconversievernootschappen, waarbij de economische ontwikkeling van bepaalde streken het uitgangspunt is. In 1979 werd een wetsontwerp ingediend tot wijziging van de gecoördineerde wetten op handelsvennootschappen van ],935 (Gedr. St. Kamer 387 $(1979.1980, \mathrm{nr} .1)$ in welk wetsontwerp de algemene introductie wan o-aandelen wordt mogelijk gemaakt. Vgl. B. van Bruystegem, RW 1985, p. 1906 e.v. Inmiddels ligt daar ook het voorstel Hatry/Cooreman (Gedr. St. Senat 607 (1986-1987) nr. 1) van 9 juli 1987, strekkende om door wijziging van eerdergenoemde gecoördineerde wetten onder meer de uitgifte van aandelen zonder stemrecht mogelijk te maken. In Frankrijk kent men de "Actions a dividende prioritaire sans droit de vote" (Loi no. 78-741 wan 13 juli 1978, rela tive à l"ortentation de l'épargne vers le financement des entreprises, Titel III, de art. 14-23). In de BRD kent men reeds sind 1937 de "Vorzugsaktien ohme: Stimmrecht" (\$ $139 \mathrm{Aktg}$. (1965) e.v.). Ook Engeland kent sinds decennia de mogelijkheid tot uitgifte van al dan niet preferente aandelen met beperkt of uitgesloten stemrecht. In $Z$ witserland kent men Partizipationsscheine, in feite aandelen zonder stemrecht (vgl. C. Hoffman, Der Partizípationsschein oder die Stimmrechtslose Aktie, Diss. Zürich 1976).

In Spanje werden o-aandelen geintroduceerd bij Wet van 25 juli 1989, Boletin Oficial del Istado 17832 .

Ook op de Antillen kent men, sinds de Landsverordening tot wiziging van het Wetboek van Koophandel wan de Nederlandse Antillen d.d. 3 september 1987 , o-atandelen. Hetzelfde geld voor Aruba, waar bij de invoering van de Aruba Exempt Company (AEC)(Landsverordening wan 30 juni 1988) owandelen werden geintroduceend.

Ook in het recente voorstel vain de Raad van de $\mathrm{EG}$ voor een verordening betreffende het statunt voor de Europese vennootschap (Pb EG 16.10.1989, Nr. C. 263/41 e.w.) wordt voorzien in de mogelith heid van emissite van o-aandelen. Art. 92 wan dit voorstel opent de mogelijk heid dat de statuten woorzien in een beperking of uitsluiting van het stemrecht voor aandelen: ". . waraan bijzondere woorrechten zijn verbonden".

Vgl. R. Faasen, Aandelen zonder stemrecht, een rechtzvergelijkend onderzoek, in D. Kokkini-latridou/F.W. Groshejde: 'Eenwormig en vergelijkend privatrecht 1989', Vermande 1989, p. 455 e.v. A. Bauer, Partizipationsscheine im Schweizer Aktienrecht im Vergleich zum Deutschen Aktienrecht, Zürich 1975 en voor Engeland, Farrar's Company Law. Butterworths, London and Edinburgh 1988, p. 190 e.v. 


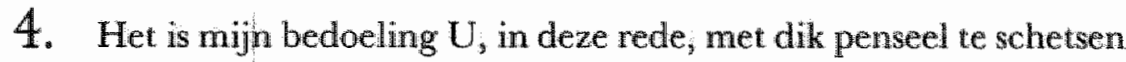
hoe in mijn visie de introductie van aandelen zonder stemrecht in ons nationale vennootschapsrecht vorm gegeven zou kunnen worden. In eerste instantie richt ik mij daarbij op de publieke NV.

Wanneer over zodanige introductie gedacht wordt, doemt een groot aantal vragen aan de einder op: laat de wet introductie van aandelen zonder stemrecht toe, hoe wordt het gemis aan zeggensmacht gecompenseerd, onder welke omstandigheden zou toch besloten moeten worden tot het bestaan van zeggensmacht, wat moet de verhouding tussen stemrechtloze aandelen en gewone aandelen zijn en hoe worden de financiële belangen van de houder van het stemrechtloos-aandeel (verder o-aandeel) gewaarborgd?

De wettelijke regeling met betrekking tot NV en BV lijkt inderdaad geen ruimte te bieden voor introductie van aandelen zonder stemrecht. De wet bepaalt dat slechts aandeelhouders stemrecht in de algemene vergadering hebben, terwijl iedere aandeelhouder tenminste één stem moet toekomen. ${ }^{18}$ Introductie van 0 -aandelen zal aanpassing van wetgeving vergen. Overigens kan worden opgemerkt dat het thans regelmatig voorkomt dat het aan aandelen verbonden stemrecht niet kan worden uitgeoefend.

Zowel de wet als de Departementale Richtlijnen 1986 laten deze situaties toe. Men denke bijvoorbeeld aan de wettelijke bepaling die de mogelijkheid schept statutair het stemrecht te onthouden aan aandelen die worden gehouden door een persoon, die bij het te nemen besluit., anders dan als aandeelhouder, bevoordeeld zou kunnen worden. ${ }^{19}$ Een ander voorbeeld is de bepaling die, ten aanzien van de BV, regelt dat stemrecht op aandelen niet kan worden uitgeoefend wanneer van die aandelen certificaten aan toonder uitstaan. ${ }^{20}$ Ook bij omzett.ng van een NV in een BV kan de situatie ontstaan waarin sterrirecht aan aandelen wordt onthouden, namelijk zollang inschrijving van de aandelen in het door de BV gehouden register van aandeelhouders niet heeft plaatsgevonden. ${ }^{21}$

De Departementale Richtlijnen laten bijvoorbeeld de statutaire regelling toe, volgens welke aandeelhouders het stemrecht kan worden

18. Art. 2:118 en $228 \mathrm{BW}$.

19. Art. 2:119 en $229 \mathrm{BW}$.

20. Art 2:202 BW.

21. Art 2:183 lid 3 BW. Zie, in werband met deze problematick, uitgebreid D.F.M.M. Zaman, TVVS 82/12 (1982), p. 300 e.v. 
ontnomen, bij het niet meer voldoen aan statutair gestelde kwaliteitseisen. ${ }^{22}$

Bij introductie van o-aandelen ontstaat een nieuwe categorie aandelen die, in vergelijking met gewone aandelen, zeggensmacht binnen de algemene vergadering mist. De vraag of het scheppen van stemrechtloze aandelen gerechtvaardigd kan worden, kan mijns inziens bevestigend worden beantwoord, ook bezien vanuit de positie van de kapitaalverschaffers. ${ }^{23}$ Zoals bekend hecht de kapitaalverschaffer, wooral binnen de zeer grote publieke vennootschap, niet steeds aan de uit die deelneming voortvloeiende zeggensmacht. Dit geldt dan vooral die aandeelhouders die als belegger participeren.

Dat dit per definitie kleine aandeelhouders zijn, moet betwijfeld worden. Zoals bekend is ook de betrokkenheid en de wens tot bestuurlijke inbreng bij grote participaties door institutionele beleggers veelal gering en staat ook daar het verlangen naar een rustig bezit met prettig rendement voorop. ${ }^{24}$

Hoewel recent onderzoek op dit punt ontbreekt, althans mij niet bekend is ${ }^{25}$, mag worden aangenomen dat een overgrote meerderheid der aandeellhouders in grote publieke vennootschappen niet in zeggensmacht is geinteresseerd. Wat hiervan de oorzaak zou kunnen zijn, bijvoorbeeld de vraag of het op ruime schaal bestaan van oligarchische regelingen bijdraagt aan het gevoel van onmacht van de aandeelhouder met als resultaat desinteresse, moet in het midden gelaten worden.

Dat zeggensmacht bij aandelen in het algemeen (ook) niet financieel wordt gewaardeerd, zou kunnen blijken uit een vergelijking over een

22. Vgl. 24 en 34 Departementale Richtlijnen 1986. Ook andere statutaire regelingen volgens welke stemrecht kan worden opgeschort of onthouden in bepaalde situaties zijn toegestaan. Zie bijv. 825 en 35 van de Richtlijnen i.v.m. de uitoefening van prioriteitsnechten. 23. Zie voor een historischie schets van de aandeclhouderspositie W.J. Slagter, Macht en onmacht van de andeelhouder, Kluwer 1988. De auteur ziett als logisch eindpunt in de ontwikkeling wan de aandeelhouderspositie het scheppen van aandelen zonder stemrecht. 24. Vgl. W.S.P. Fortuyn c.s., Competitie en Bescherming, SMO-boek, Den Haag 1990.

25. Ouder onderzoek is bijwoorbeeld verricht door de Stichting Maatschappij en Onderneming (SMO), Machtsverdeling in de Naamloze Vennootschap, Den Haag 1971, uit welk onderzoek bleek dat bij $62 \%$ van de onderzochte grote beurswennootschappen het opkomstpereentage $20 \%$ of minder bedroeg. Op het recentelijk gehouden congres "Beschermingsconstructies' te Nijmegen deelde R.P. Voogd mede dat een vergelijkbaar slecht opkomstpercentage zich ook thans nog hat zien. Zelfs op momenten van besluitvorming over cruciale zaken wordt veelal ternauwernood $50 \%$ gehaald. Zie ook zijn dissertatie, a.w. noot $\mathbb{1 3}$, p. 389. 
langere periode van koerswaarde van aandelen en koerswaarde van certificaten van deze aandelen in die gevallen waarin beursnotering van beide varianten plaats heeft. Bij kennisneming van de beurspagina lijken mij significante verschillen in waardering niet waarneembaar.

$\mathrm{Bij}$ het o-aandeel komt het accent geheel te liggen op de vermogenswaarde van de aandelen. In dat licht is zeer wel voorstelbaar de aan deze aandelen verbonden dividend-aanspraken, in vergelijking met de gewone aandelen, te versterken. Dit kan geschieden door aan de o-aandelen een preferente of een cumulatief preferente dividend-aanspraak te verbinden, waarbij tevens een al dan niet winstdelend karakter kan worden gecreëerd. ${ }^{26}$ Door zodanige accentuering van het puur-vermogensrechtelijke karakter kan de attractiviteit voor de belegger worden verhoogd, wat kan bijdragen tot de geschiktheid van deze aandelen als financieringsmiddel voor de vennootschap. De preferente dividendaanspraak biedt compensatie voor het ontbreken van zeggensmacht.

Indien het o-aandeel preferent zou zijn en geen aanspraak zou geven op verdere winstdeling, zou het zeer gaan lijken op een obligatie. Enig verschil zou zijn dat aflossing van de vennootschappelijke schuld, na uitloting of op zekere datum, niet plaatsvindt nu het gefourneerde bedrag niet wordt geleend maar, risicodragend, ter beschikking wordt gesteld. Op de mogelijkheid van intrekking van o-aandelen onder terugbetaling van gestort kapitaal kom ik hieronder terug. Zo"n aandeel zou als financieringsmiddel onaantrekkelijk zijn, nu in dat geval, gezien het karakter van de participatie, volstaan zou kunnen worden met storting vàn het nominale bedrag van het aandeel. Daarnaast zou de preferente dividend-aanspraak, wil men beleggers interesseren, pittig moeten zijn, een situatie die gewone aandeelhouders in veel gevallen niet tot vreugde zal stemmen.

Een keuze voor een preferent winstdelende aandeel lijkt hier geïndiceerd. Ter compensatie van het ontbreken van zeggensmacht kan aan deze aandelen een lage preferente aanspraak worden toegelkend, terwijl deze aandelen vervolgens, op voet van gelijkheid met gewone aandelen, in de winst delen.

26. In de diverse rechtssystemen die owaandelen kennen wordt vaak een preferente winst:aanspraak gecreëerd. In sommige systemen wordt de minimumaanspraak wettelijk vastgelegd (bijw. Spanje minimal 5\% en Belgie wolgens de voorgestelde regelingen eveneens 5\%). Vaak is zodlanige preferente anspraak cumulatief (Duitsland, Belgie) of geldt cen beperkte cumulatie (Spanje). Ook komen o-aandelen voor zonder preferente aanspraken. Deze worden aangetroffen in de Anglo-Amerikaans georienteerde systemen. 
De vraag is welke de preferente aanspraak zou moeten zijn. Deze aanspraak zou zodanig gekozen moeten worden dat enerzijds een voldoende impuls tot neming bij het beleggend publiek wordt veroorzaakt, terwijl anderzijds de omvang voor houders van gewone aandelen aanvaardbaar moet zijn. Uiteraard dient vaststelling van het preferent percentage aan de vennootschap te worden overgelaten. Ter bescherming van kapitaalverschaffers dient in mijn visie echter een benedengrens te worden bepaald. De vraag of dit minimum preferent percentage wordt uitgekeerd is vervolgens bepalend voor de vraag of aan de o-aandelen stemrecht wordt toegekend. Ik kom hierop dadelijk terug. Als wettelijk voorgeschreven minimum-percentage will ik $3 \%$ voorstellen, met dien verstande dat het de vennootschap vrij staat een hoger percentage te hanteren.

De preferente aanspraak van minimaal $3 \%$ van de nominale waarde van het aandeel levert de 0 -aandeelhouder een vorm van garantie-rendement op. Het lijkt dan ook voor de hand liggend dit minimum preferent dividendrecht cumulatief te doen zijn. De vennootschap heeft de vrijheid de preferente aanspraken, al dan niet cumulatief, hoger vast te stellen.

Structurering van het aandeel op deze wijze zou leiden tot volledige financiele participatie van de o-aandeelhouder. Nu hij ook tot de reserves gerechtigd wordt, dient, in voorkomende gevallen, agio te worden gestort. Dit zou ertoe leiden dat, bij het aantrekken van risicodragend kapitaal, minder o-aandelen geëmitteerd hoeven te worden, wat het totaal van de preferente aanspraken beperkt.

5. De vraag is vervolgens hoe men de positie van de o-aandeelhouders binnen de vennootschap verder vorm kan geven. Voorop staat dat de o-aandeelhouder aandeelhouder is. Enig verschil is dat deze aandeelhouder het recht ontbreekt om binnen de algemene vergadering van aandeelhouders stemrecht uit te oefenen. Indien deze bevoegdheid ontbreekt, laat de positie van de o-aandeelhouder zich goed vergelijken met die van de houder van met medewerking van de vennootschap uitgegeven certificaten. Evenals deze certificaathouders heeft hij het recht de algemene vergadering bij te wonen, aldaar het woord te woeren, een geautoriseerde bijeenroeping te bewerkstelligen, de jaarstukken in te zien en kosteloos een afschrift daarvan te ontvangen 
en bijvoorbeeld een enquêteprocedure uit telokken. Gezien het feit dat o-aandeelhouders ter algemene vergadering geen stemrecht toekom: meen ik dat $\mathrm{zij}$ niet mee dienen te tellen bij de vaststelling van een quorum. Naar huidig recht brengt art. 2:24d BW dit overigens al met zich mede. De o-aandeelhouder is als aandeethouder gerechtigd een beroep te doen op de art. $2: 11$ jo. $13 \mathrm{BW}$ en is uiteraard, als aandeelhouder, belanghebbende in de zin van art. $999 \mathrm{Rv}$.

Kortom, de o-aandeelhouder heeft alle bevoegdheden die aan aandeelhouders toekomen, behalve het als aandeelhouder uitoefenen van stemrecht. Hij kan zich als aandeelhouder dan ook jegens (organen van) de vennootschap of mede-aandeelhouders beroepen op de gedragsregel van art. 2:7 BW. ${ }^{27}$ Overigens zou $\mathrm{ik}$, in afwijking van het thans in art. 2:96a lid $2 \mathrm{BW}$ bepaallde, de houders van o-aandelen geen voorkeursrecht willen toekennen bij emissie van aandelen van welke soort dan ook. Door toekenning van zodanig voorkeursrecht zou de juist door introductie van o-aandelen aan te brengen splitsing in soorten aandeelhouders in gevaar komen. Tegen een voorkeursrecht voor houders van aandelen met stemrecht bij emissie van o-aandelen lijken minder bezwaren te bestaan.

Naast deze aandeelhoudersrechten lijkt het aanbevelenswaardig aan o-aandelen, onder nauwkeurig omschreven omstandigheden, ook zeggensmacht als aandeelhouder te verbinden. ${ }^{28}$ Toekenning van zeggensmacht zal zich, in mijn visie, voor moeten doen in die gevallen waarin de vermogenswaarde van de o-aandelen ernstig dreigt te worden aangetast.

Allereerst zou dan gedacht kunnen worden aan gevallen waarin de vennootschap niet overgaat tot uitkering van het minimum preferent dividend. In deze situatie zou stemrecht aan het o-aandeel verbonden kunnen worden. Op deze wijze fungeert het ontstaan van het stemrecht

27. Als werschil tussen de positie van o-aandeellhouders en die van certificathouders kan worden aangemerkt het feit dat het administratiekantoor, bij tutoefening van het stemrecht op de aandelen, het (frnancieel) belang van certilicaathouders zwar moet laten wegen. Op deze wijze valt een wom van indlirecte zeggensmacht te construeren, watarwan de onvarg zal afhangen van administratievoorwarden en de feitelijke werhouding van certificaathouders tot het administratiekantoor. Zodanige situatie is ten aarizien van 0 -aandeclhouders niet waarneembaar. Aan o-aandelen is immers in principe geen stemrecht verbonden. Ook hieruit kan een argument worden geput de positie van de o-aandeehouder in bepaalde situaties taader te versterken.

28. Zodanige constructie wordt, overigens met verschillende invulling, in de meeste systemen waarin o-aandelen woorkomen, gehanteerd. Vgl bijv. \$ 140 lid 2 Aktg. waar volledig stemrecht an a-aandeten word verbondlen indien in 2 jaren het gecumuleerd preferent dividend niet wordt uitgekeerd, en \$141 Alktg., waar goedkeuring van de 
enerzijds als mogelijkheid om, met gebruikmaking van het stemrecht, in dat geval bemoeienis met het vennootschappelijk beleid te kunnen hebben, terwijl anderzijds het latent aanwezige stemrecht als stimulans voor het bestuur van de vennootschap zal functioneren om het rendement op aandelen te maximaliseren, althans voldoende winst te genereren om tot uitkering van het minimum preferent dividend over te gaan. Indien een hoger preferent dividend aan de o-aandelen is verbonden en het boven-minimale percentage niet kan worden uitgekeerd, lijkt mij het ontstaan van stemrecht niet geindiceerd. De $3 \%$ behelst de basisvergoeding woor het ontbreken van zeggensmacht. Afgezien van deze extra aanspraak is het financieel lot van de o-aandeelhouder gelijk aan dat van andere aandeelhouders. Behalve de mogelijkheid van stemming binnen de algemene vergadering, heeft de o-aandeelhouder dezelfde actie-instrumenten als een gewone aandeelhouder, zoals bijvoorbeeld bijeenroeping van een algemene vergadering en het ventileren van zijn visie aldaar, of het uitlokken van een enquêtteprocedure.

Opgemerkt kan worden dat de dividend-politiek, c.q. het functioneren van het bestuur, de waarde van vooral het o-aandeel direct beĩnvloeden. Indien het minimum preferent dividend niet wordt uitgekeerd, neemt de handelswaarde van het 0 -aandeel, zeker voor de kleine beleggers, direct in ruime mate af. Juist de preferente aanspraak zal het o-aandeel als beleggingsinstrument aantrekkelijk maken. Gezien deze te voorspellen directe waardedaling, is het voor de hand liggend het feitelijk verlies van de preferente rechten te compenseren met toekenning van stemrecht binnen de vennootschap. Zoals hiervoor werd opgemerkt is binnen andere rechtssystemen niet ongebruikelijk dit

- vergadering van o-aandeellhouders wordt geëist bij besluiten waarbij de pneferentie, die in de BRD overigens niet aan een wettelijk minimum wordt gekoppeld, wordt beperkt of opgetheven of waarbij tot emissic van preferente aandelen met een hogere of gelijke preferentie word. besloten. Zie ook G. Reckinger, AG 8/1983, p. 216 e.v. In het Belgische ontwerp Hatry/Cooreman wordt ook voorzien in het ontstaan van stemnecht indien het cumulatief preferent dividend in twee opvolgende jaren niet wordt uitgekeerd. Daarnaast wordt in $\$ 2$ van dit ontwerp een fors aantal besluiten genoemd, zoals ontbinding of doelwijziging van de vemnootschap, bij welke besluiten an o-atandeelhouders stemrecht in de algemene vergade* ring zou moeten toekomen. In Frankrijk kent men een ander systeem, waarin de vergadering van 0 -aandeelhouders steeds het recht heelt dhatir zienswijze te formuleren en via vertegenwoordigers in de algemene vergadering naar woren te brengen. Daarnaast kunnen daar besluiten, die raken aan de mechten wan o-aandeelhouders, slechts worden gemomen na verkregen instemming van o-aandeelhouders. In Spanje kent men cen systeem waarin stemrecht onstaat wanneer in enig jaar het preferent dividend (van minimaal $5 \%$ ) niet wondt witgelkeerd. Oolk hier het vereiste van een instemmend beshuit van de vergadering van o-aandeelhouders voor ellke statutenwijziging die belangen wan o-aandeelhouders rechtstreeks raakt. 
stemrecht te doen ontstaan wanneer over langere tijd het cumulatief preferente dividend niet ten volle is uitgekeerd. ${ }^{29}$

Ik zou willen voorstellen de mogellijkheid tot het verkrijgen van stemrecht te creëren wanneer in enig jaar niet het volledig minimum preferent dividend wordt uitgekeerd. Gezien het feit dat, naar verwachting, ook in deze situaties de wens tot actieve participatie binnen de vennootschap niet groot zal zijn, is voorstelbaar de zeggensmacht slechts aan die o-aandelen te verbinden waarvan de eigenaar zulks aan de vennootschap verzoekt. ${ }^{30}$ In mijn voorstelling zou het stemrecht aan de desbetreffende o-aandelen verbonden kunnen blijven tot het moment waarop de totale preferente aanspraak van de o-aandeelhouder is uitgekeerd.

Het beginsel van de gelijkheid van o-aandeelhouders zou overigens met zich mee moeten brengen dat een uitkering van preferent-dividend gelijkelijk over alle uitstaande o-aandelen plaatsvindt.

Tegen het argument dat op deze wijze de bevoegdheidsverdeling binnen de vennootschap te zeer wordt verbonden aan het resultaat van de vennootschap, kan worden aangevoerd dat er mijns inziens geen aanvaardbare reden is de 0 -aandeelhouder het stemrecht te onthouden wanneer het gegarandeerde minimum-rendement op de aandelen niet wordt gehaald. Daarnaast zou het stemrecht in mijn opvatting eerst ontstaan wanneer de aandeelhouder daarom verzoekt. ${ }^{31}$

Als sluitstuk op deze regeling zou gedacht kunnen worden aan het aanleggen van een systeem waarin, indien in een periode van 3 jaren onvoldoende preferent dividend is uitgekeerd, het stemrecht, verbonden aan o-aandelen, van rechtswege ontstaat.

29. Zoals gezegd hanteert men in de BRD en denkt men in Belgie aan een termijn van 2 jaren. In Spanje kent men een periode van 1 jaar. Het niet uitgekeerde dividend cumuleert en moet in de volgende 5 jaren worden uitgekeerd. Gedurende deze periode bestaat de dividend aanspraak en is aan de o-aandelen stemrecht verbonden. Na ommekomst van deze termijn vervalt de aanspraak en het stemrecht. In thet Belgische ontwerp gat men witt wan een periode van twee opeenwolgende jaren waarin het cumulatief preferent dividend niet is uitgekeerd, terwijl stemrectit aan de aandelen verbonden blyfft tot het moment waarop de dividend-achterstand is ingelopen.

30. Ter vermijding van onduidelijke situaties ter algemene vergadering lijkt het noodztakelijk een procedute in te stellen waarlangs de o-aandeelhouder stemnecht ter algemene vergadering kan werkrijgen. Hierbij kan gedacht worden aan een depot van o-aandelen met bijbehorende verklaring op stemrecht ter algemene wergadering aanspraak te maken. Voor een rechtsgeldig verkrijgen van stemrecht zou als voorwaarde gehanteerd kunnen worden dat verrichten van het depot en afleggen van bijbehorende verklaring bijvoorbeeld 7 werkdagen vơơr de datum van de vergadering inoet hebben plaatsgevonden.

31. Hierdoor wordt aansluiting verkregen bij het voorstel van Van der Grinten in de Verdam-bundel, "Uit het Recht' (Deventer 1971), p. 295 e:w. In dit boeiende stuk gatic hij in op machtsverhoudingen binnen de vennootschap bij eventuele introductie war aandelen - 
Gezien bet feit dat naar verwachting ook in deze situatie de gemiddelde o-aandeelhouder niet zal hechten aan zeggensmacht, zou door deze regeling de druk op het bestuur van de vennootschap wellicht worden verhoogd. Hiertegenover kan worden gesteld dat die druk toch wel aanwezig zal zijn nu de mogelijkheid van een onwriendelijke overname in deze situaties levensgroot is. Aan een automatisch verbinden van stemrecht aan o-aandelen is mijns inziens geen behoefte.

De o-aandeelhouder zal in deze omstandigheden zelf kunnen beoordelen of al dan niet gebruik gemaakt zal worden van het latent aanwezige stemrecht.

De wettelijke regeling met betrekking tot de mogelijkheid van uitkering van dividend waarborgt mijns inziens overigens dat de vennootschap niet tot uitkering van preferent dividend zal kunnen overgaan indien de resultaten dit niet toelaten.

6. Een andere vraag is of de houder van o-aandelen ook in andere situaties zeggensmacht in de algemene vergadering moet toekomen. Te denken valt aan de bevoegdheid tot uitoefening van stemrecht in het kader van een speeifiek te nemen besluit, dan wel aan toekenning van een indirecte mogelijkheid van beinvloeding van besluitvorming, bijvoorbeeld in de sfeer van goedkeuring van bepaalde besluiten van de algemene vergadering door de vergadering van o-aandeelhouders. Hier kan gedacht worden aan al die besluiten van de algemene vergadering, die direct de vermogenswaarde van de o-aandelen beïnvloeden. Ik denk dan aan besluiten tot ontbinding van de vennootschap, tot emissie van aandelen, tot vermindering van kapitaal, of tot fusie.

Om met het besluit tot ontbinding te beginnen: zodanig besluit raakt het financiedl lot van de aandeelhouder direct. Het al dan niet nemen

$\rightarrow$ Monder stemincht. Hij betwijtelt of zodanige introductie aantrekkelijk is en stelt een tussenoplossing woor, hieruit bestande dat het stemrecht wordt verbonden aan aandelen op naam, terwijl andelen aan toonder geen stemrecht zouden kemen. De toonder-andeelhouder zou stee ds in stat moeten zijn, door verwisseling van zijn toonderstuk in een aandeel op naam, het stemrecht te verkrijgen. In dit voorstel wordt een syyteem gecreeterd dat sterk lijkt op hantering van royeerbare certificaten. Ik meen dat imtroductie van o-aandelen, zoals thans voorgesteld, de voorkeur zou verdienen. Voordeel zou zijn dat van meet al aan duidelijk is welke aundelen stemrecht toekomt, terwijl een beschermingssysteem eenvoudig zou kunnen worden aangelegd. Het gevalar wan misstanden als waaraan Van der Grinten denkl, lijk mij, de thans voorgestelde regeling overziende, niet groot. 
van zodanig besluit zal afhangen-van onder meer-de financiele positie en de inschatting van het earningpotentieel op termijn.

Betrokkenheid lijkt mij hier voor de hand liggen in die zin dat iedere o-aandeelhouder in staat moet zijn invloed uit te oefenen op de totstandkoming van dit besluit. Hierbij zou gedacht kunnen worden aan het verbinden van stemrecht aan o-aandelen binnen de algemene vergadering van aandeelhouders, waar het betreft besluitvorming op dit punt. Bezien vanuit de systematiek van het hieronder nader uit te werken systeem, lijkt het mij echter beter een regeling te scheppen, inhoudende een vereiste van een voorafgaand goedkeurend besluit van de vergadering van o-aandeelhouders, voor zover althans de ontbinding van de vennootschap afbreuk zou doen aan de financiële rechten van o-aandeelhouders. Van zodanig afbreuk doen aan rechten zou sprake zijn wanneer duidelijk is dat de wennootschap, na de ontbinding, niet in staat zou zijn het door de o-aandeelhouders gestorte kapitaal aan hen uit te keren. Of wór de ontbinding hieromtrent duidelijkheid kan worden verkregen; zal afhangen van de situatie. In veel gevallen zal dit niet tot de mogelijkheden behoren. Het lijkt dan ook noodzakelijk een besluit tot ontbinding steeds aan voorafgaande goedkeuring van de vergadering van o-aandeelhouders te onderwerpen. Indien omtrent ontbinding wordt besloten in een periode waarin stemrecht aan de o-aandelen zou zijn verbonden, meen ik dat goedkeuring van zo'n besluit door de vergadering van o-aandeelhouders eveneens vereist zou moeten zijn. Waarborging van hun financieel belang lijkt zodanige regeling noodzakelijk te maken.

In het kader van de bevoegdheidsverdeling rond het besluit tot uitgifte van aandelen, kan worden volstaan met een regeling als thans in art. 2:96 BW wordt aangetroffen, wanneer althans de bepaling in lid 2 van dit artikel restrictief wordt geïnterpreteerd. Aan o-aandeelhouders behoeft geen zeggensmacht toe te komen bij besluitvorming in de algemene vergadering over emissie van aandelen, of aanwijzing door die vergadering van een ander orgaan dat de emissiebevoegdheid ont* vangt. Dit ligt niet anders in die gevallen waarin het besluit tot uitgifte of aanwijzing afbreuk doet aan de rechten van o-aandeelhouders. In dat geval dient, ingevolge de regeling van lid 2 van art. 2:96 $\mathrm{BW}$, het. besluit afhankelijk te zijn van een goedkeurend besluit van de vergadering van o-aandeelhouders. Wanneer van 'albreuk aan rechten' sprake is, is niet geheel duidelijk. Uit de parlementaire geschiedenis blijkt dat dit afbreuk doen vooral in de financiële sfeer wordt geplaatst, en dat kan ook niet anders. Immers, bij emissie van aandelen zonder hantering 
van een voorkeursrecht, wordt steeds afbreuk gedaan aan de rechten van aandeelhouders in die zin dat, althans bij aandelen met stemrecht, de relatieve zeggensmacht binnen de algemene vergadering verwatert.

Wanneer in die gevallen steeds goedkeuring van de houdlers van aandelen van een bepaalde soort vereist zou zijn, zou de emissiebevoegdheild of delegatiebevoegdheid steeds beperkt zijn door een veto-recht. ${ }^{32}$ Sprekende over de positie van de houders van o-aandelen is deze discussie , nu er geen zeggensmacht is en er dus niets valt te verwateren, niet relevant. Het gaat hier - afgezien van situaties waarin wel generaal stemrecht aan de o-aandeelhouder toekomt uitsluitend over de vraag of afbreuk wordt gedaan aan financiële rechten van de houders van aandellen van deze soort, waarbij moet worden opgemerkt dat, in mijn visie, de houder van o-aandelen geen voorkeursrecht toekomt. Van bedoelde afbreuk zou sprake kunnen zijn, de toelichting volgend ${ }^{33}$, wanneer aandelen met een hogere preferentie worden uitgegeven. Het bestaan van zodanige situatie zou ik tevens willen aannemen in het geval waarin aandelen met een gelijke preferentie worden geëmitteerd. Dat in zo'n situatie steeds sprake zal zijn van afbreuk aan financiële rechten zou kunnen worden betwijfeld. Ter voorkoming van discussies zou afbreuk in zodanige situatie aangenomen kunnen worden, waarbij een rol kan spelen dat 0-aandeelhouders niet betrokken zijn bij eventuele besluiten tot statutenwijziging, die zodanige emissie mogelijk moeten maken. Een weigering van goedkeuring zou door de rechter getoetst kunnen worden.

Een ander voorbeeld zou kunnen zijn de emissie van aandelen waarbij de uitgiftekoers te laag wordt bepaald. In die gevallen immers wordt de vermogenswaarde van het aandeel direct geraakt. Gezien het feit dat in het kader van deze besluitvorming de o-aandeelhouder geen stemrecht in de algemene vergadering toekomt, zou, nu zodanig besluit afbreuk aan rechten doet, er steeds sprake moeten zijn van een voorafgaand goedkeurend besluit van de vergadering van o-aandeelhouders. Indien hierover besloten zou worden in een periode waarin, op basis van de voorgestelde regeling, stemrecht binnen de algemene vergadering ook aan o-aandeelhouders toekomt, zou dit geen verschil maken,

32. Dat in dit kader niet aan verwatering wordt gedacht, blijkt uit de NaEV bij de Aanpassingswet tweede EG-richtlijn, Maejer, Wetsgeschiedenis IX, p. - art. 317-5.

33. Vgl. MvT bij de Aanpassingswet tweede EG-richtlijn, Maeijer, Wetsgeschiedenis IX m Art. 96, p. 2. 
behalve dan dat, in plaats van een voorafgaand goedkeurend besluit, een gelijktijdig goedkeurend besluit van o-aandeelhouders tot de mogelijkheden zou behoren.

7. Gelijksoortige situaties doen zich voor bij beslluiten tot vermindering van kapitaal. Ook in deze gevallen is niet volstrekt duidelijk wanneer moet worden aangenomen dat de kapitaalvermindering afbreuk doet aan de rechten van houders van aandelen van een bepaalde soort. ${ }^{34}$ Van zodanig afbreuk doen is in ieder geval sprake wanneer aandelen van die soort worden afgestempeld tot een lagere nominale waarde zonder dat terugbetaling van gestort kapitaal plaatsvindt. Dit spreekt vooral bij afstempeling op deze wijze van o-aandelen, nu deze aandelen immers een aan de nominale waarde gerelateerde aanspraak op preferent dividend met zich brengen. De vraag of sprake kan zijn van afbreuk doen aan financiële rechten van o-aandeelhouders indien een andere categorie aandelen wordt ingetrokken met terugbetaling van gestort kapitaal, lijk mij onder omstandigheden bevestigend beantwoord te kunnen worden. Men denke hier aan de situatie waarin, bij slechte financiële conditie van de vennootschap, een categorie aandelen wordt ingetrokken, bijvoorbeeld preferente beschermingsaandelen waarop $25 \%$ is gestort. In dat geval immers wordt niet alleen vennootschappelijk vermogen aan de vennootschap onttrokken doordat dit wordt teruggestort, maar wordt tevens afstand gedaan van de mogelijkheid volstorting van die aandelen te verlangen.

Ook in gevallen als deze lijkt toekenning van stemrecht aan o-aandeelhouders niet voor de hand te liggen. Die besluitvorming vindt plaats door de stemgerechtigde aandeelhouders. Indien de kapitaalvermindering afbreuk doet aan de rechten van o-aandeelhouders, zal een voorafgaand goedkeurend besluit van de vergadering van o-aandeelhouders op de voet van art. 2:99 lid 5 BW vereist zijn.

34. Vgl. art. 2:99 lid 5 BW. 
8. Een besluit tot fusie, althans de uitvoering van dat besiuit, kan zeer wel geacht worden afbreuk te doen aan de financiële rechten van de a-aandeelhouder. Men denke hier dan aan een juridische fusie, tussen een verdwijnende vennootschap die o-aandelen heeft uitgegeven en een verkrijgende vennootschap die geen o-aandelen, althans geen preferente aandelen, kent. Nu een bevredigende ruilverhouding niet zal zijn te creëren en andersoortige aandelen danwel contanten zullen moeten worden aangeboden, lijkt het belang van o-aandeelhouders in het geding te kunnen komen. ${ }^{35}$

Ook in deze situaties behoeft de o-aandeelhouder, in het kader van de besluitvorming in de algemene vergadering, geen zeggensmacht te worden gegeven. In gevallen als deze zou eveneens volstaan kunnen worden met de regeling van art. $2: 330 \mathrm{BW}$, in die zin dat een voorafgaand goedkeurend besluit van de houders van o-aandelen vereist is.

Een vergelijkbare moeilijkheid als geschetst in het kader van de fusie, zou zich theoretisch voor kunnen doen bij omzetting van de vennootschap in een andere rechtsvorm. Nu het o-aandeel een rol zal spelen binnen de grote publieke beursgenoteerde NV, zal zodanige omzetting zich zelden voordoen. In voorkomende gevallen zou ik ook geen voorstander van het verlenen van stemrecht in de algemene vergadering zijn, doch willen volstaan met een voorafgaand goedkeurend besluit van de vergadering van houders van o-aandelen, voor zover althans het omzettingsbesluit afbreuk doet aan de financiele belangen van o-aandeelhouders.

Naar ik meen is de betrokkenheid van o-aandeelhouders bij cruciale besluiten van de algemene vergadering op deze wijze globaal verzekerd. Als sluitstuk op dit alles zou tenslotte gedacht kunnen worden aan formulering van een algemene regel, die een besluit tot statutenwijziging van de vennootschap onderwerpt aan een voorafgaand goedkeurend besluit van de vergadering van o-aandeelhouders, in die gevallen waarin door de wijziging van de statuten afbreuk aan hun rechten wordt gedaan.

35. Vgll. de Nota natar anleiding van het Eindverslag bij de Wet tot regeling van de fusie van namioze en besloten wennootschappen (Wet van 19 januari 1983 , Stb. 1983, 59, $I^{\mathbb{E}} \mathrm{K}$, zitting $1981-1982,16453$, nr. 11 , war de Minister t.a.v. lid 5 van art. 2:317 BW (oud) opmerkt: 'Bij fusie met oprichting van een nieuwe vennootschap is er geen stafutenwijziging, maar kan zeer wel afbre ulk an rechten worden gedaan; bijvoorbeeld in hel geval dat de statuten varu een verdwijnende vemootschap aan een soort aandelen preferentie toe-

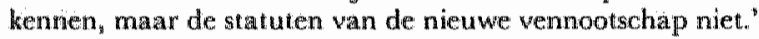


Samenvattend zou mijn voorstel zijn de o-aandeelhouders, bij besluiten die hun financiële positie raken, geen directe zeggensmacht in de algemene vergadering te verlenen. In die gevallen wordt volstaan met een regeling, waarin de vergadering van o-aandeelhouders een voorafgaand goedkeurend besluit dient te nemen.

Mijns inziens wordt op die manier het belang van o-aandeethouders het best beschermd. Indien wel zou worden gekozen voor stemrecht in de algemene vergadering, kan immers worden aangenomen dat o-aandeelhouders steeds worden overstemd door houders van gewone aandelen. Hierbij speelt het in die gevallen te verwachten geringe opkomstpercentage van o-aandeelhouders een rol. Bij een systeem van 0 -aandelen zal het opkomstpercentage van houders van gewone aandelen steeds hoger liggen. Die aandelen werden immers genomen door participanten die juist in zeggensmacht geünteresseerd zijn.

Een nadeel van mijn voorstel zou kunnen zijn dat, uitgaande van geringe opkomst, ter vergadering van o-aandeelhouders aan een kleine minderheid een vetorecht wordt gegeven ten aanzien van door de algemene vergadering te nemen besluiten. Ik acht dit, gezien het feit dat besluiten tot weigering van goedkeuring steeds aan rechterlijke toetsing onderworpen kunnen worden, geen bezwaar.

$\mathrm{Na}$ in grote lijnen enkele vragen rond de introductie van o-aandelen te hebben behandeld, blijven legio vragen over, welke minder gericht zijn op de positie van de o-aandeelhouder, maar betrekking hebben op de organisatie van de vennootschap. Essentieel daarbij is de vraag welk soort vennootschap tot emissie van o-aandelen in staat zou moeten zijn en tot welk bedrag, en of het karakter van financieringsmiddel met zich brengt dat de intrekking met terugstorting van kapitaal steeds mogelijk zou moeten zijn.

9. Voor beantwoording van de vraag welke vennootschap tot emissie van o-aandelen in staat gesteld zou moeten worden, dient gekeken te worden naar aard en functie van het o-aandeel. Inventarisatie van verschijningsvormen van BV en NV kan hier, gezien de onduidelijke afgrenzingen van de onderscheiden karakters, geen uitkomst bieden. ${ }^{36}$

36. Zie, in verband met verschijningsvormen van de NV, F. J.P. van den Ingh, WPNR 5934 $(1989), \mathrm{p} .627 / 8$ en $5935(1989)_{\text {, p }} 647 / 8$. 
Gezien het feit dat het o-aandeel een financieringsinstrument toegesneden op de belegger is, kan als eis gesteld worden dat het o-aandeel steeds aan toonder moet lüden. Dit schakelt de categorie besloten vennootschappen als toekomstig emittent uit. Over blijft de naamloze vennootschap. De stelling zou verdedigd kunnen worden dat het oaandeel, gezien de belangen van de houders, steeds ter beurze verhandeld moet kunnen worden, zodat emissie van o-aandelen door niet ter beurze noterende vennootschappen niet mogelijk zou moeten zijn. De in grove lijnen geschetste regeling beziend, zou ik menen dat voor zodanige beperking geen grond aanwezig is. De belangen van de o-aandeelhouder lijken, gezien het ontstaan van stemrecht bij een preferent rendementtekort, alsmede gezien de mogelijkheid bij alle voorgenomen besluiten die de positie van o-aandeelhouders raken een veto te doen weerklinken, voldoende gewaarborgd.

Ik zou dan ook menen dat de mogelijkheid tot emissie van o-aandelen over te gaan, kan worden toegekend aan alle naamloze vennootschappen, ongeacht de vraag of de aandelen ter beurze noteren.

10. Daarnaast is de vraag van belang tot welk bedrag emissie van o-aandelen mogelijk dient te zijn. Een te omvangrijke mogelijkheid tot emissie van o-aandelen zou mogelijk de bijl leggen aan één der wortels van ons vennootschapsrecht, nl. het dualistisch karakter. Het praktisch verdwijnen van de algemene vergadering als orgaan van de vennootschap, zou het functioneren van het dualistisch systeem, waarin de algemene vergadering als intern sturings- en controlemechanisme functioneert, om zeep helpen. Daarnaast leidt een veelheid van andere argumenten, door o.a. Van der Grinten krachtig verwoord ${ }^{37}$, tot de conclusie dat de algemene vergadering, als elementair orgaan binnen de vennootschap, behouden moet blijven. De wezenlijke zeggensmacht dient binnen de algemene vergadering te liggen. Dat het aantal stemgerechtigde aandeelhouders relatief geringer wordt, levert geen bezwaar op. Eerder is dit een voordeel, nu slechts diegenen die in zeggensmacht en betrokkenheid geinteresseerd zijn, aandelen met stemrecht zullen houden, wat ertoe zal kunnen leiden dat de algemene vergadering ook

37. W.C.L. van der Grinten, t.a.p. noot 15 . 
werkelijk als orgaan zal functioneren. Anderzijds kan als uitgangspunt worden gehanteerd dat een gezonde verhouding aanwezig zou moeten zijn tussen omvang van zeggensmacht en het geplaatst kapitaal. Die gezonde verhouding wordt in verschillende rechtssystemen verschillend gedefinieerd. Zo wordt in Duitsland emissie van o-aandelen toegelaten tot een bedrag gelijk aan het totaal van de geplaatste gewone aandelen. ${ }^{38}$ In Frankrijk kunnen o-aandelen worden uitgegeven tot $25 \%$ van het geplaatste kapitaal. ${ }^{39}$ In Spanje opteert men voor een systeem waarin emissie van 0 -aandelen mogelijk is tot een nominaal bedrag dat niet hoger is dan $50 \%$ van het geplaatst kapitaal, althans tot maximaal $50 \%$ van het op die aandelen gestorte bedrag ${ }^{40}$, terwijl in het Belgisch voorstel wordt gekozen voor een emissie-plafond van $50 \%$ van het totale geplaatste kapitaal. ${ }^{11}$ Volgens Antilliaans recht is emissie van aandelen mogelijk tot $80 \%$ van het maatschappelijk kapitaal, terwijl $20 \%$ van het maatschappelijk kapitaal moet zijn geplaatst in de vorm van aandelen mèt stemrecht. ${ }^{42}$ Als ik het goed begrepen heb is de mogelijkheid van emissie van o-aandelen binnen de Aruba Vrijgestelde Vennootschap volgens het Arubaans Wetboek van Koophandel nog groter, en kan emissie van o-aandelen plaatsvinden wanneer tenminste één volledig stemgerechtigd aandeel wordt gehouden door een ander dan de vennootschap zelve. ${ }^{43}$ Uitwerking van de diverse systemen leidt tot verschillende resultaten.

De vraag is waar voor Nederland de grens gelegd zou kunnen worden. Het appelleert aan het redelijkheidsgevoel te oordelen dat o-aandelen niet voor een hoger bedrag uitgegeven mogen worden dan het bedrag dat aan stemgerechtigde aandelen is geplaatst. Op die manier wordt immers een situatie gecreëerd waarin de zeggensmacht niet wordt verkregen door degenen die minder kapitaal inbrengen dan door oaandeelhouders wordt ingelegd. Deze gedachtengang mag dan niet van redelijkheid zijn ontbloot, de vraag is echter of de positie van o-aandeelhouders tot zodanige begrenzing noodzaakt, dan wel of de vennootschappelijke structuur deze begrenzing dicteert. Ik meen dat een ontkennende beantwoording van deze vragen verdedigbaar is.

38. Zie 139 lid 2 Aktg. Vigl. H. Kriebel, Die AG 1963, p. 174 e.v.

39. Art. 269-1 Appendice au Code de Commence.

40. Art. 38 Wet van 25 julii 1989. Zie noot 17.

41. Art. $48 \$ 1$ sub I ontwerp Hatry/Cooreman.

42. Zie H.Th.M. Burgers, TVVS 87/11, p. 277.

43. Art. 155 G AWvK. Zie H.Th.M. Burgers, TVVS 88/10, p. 269 ev. 
Voor wat betreft de financiele belangen van o-aandeellhouders; deze lijken mij in de woorgestelde regeling voldoende gewaarborgd te kunnen worden, zodat het voor hen niet uit hoeft te maken wat de onvang is van de kapitaalinbreng van de stemgerechtigde aandeelhouders. Daarnaast meen ik dat het functioneren van de algemene vergadering binnen de dualistische vennootschappelijke organisatie slechts in beperkte mate afhankelijk is van de relatieve omvang van het aantal geplaatste aandelen van verschillende categorieën. Wel is noodzakelijk dat de algemene vergadering als werkelijk functionerend orgaan blijft bestaan, zodat haar macht ten opzichte van het bestuur van de vennootschap reèel is. Hiertoe is noodzakelijk dat een zeker aantal aandelen met stemrecht wordt uitgegeven, terwijl de zeggensmacht op die aandelen niet door het bestuur van de vennootschap wordt gecontroleerd. ${ }^{44}$

Voorstelbaar zou zijn emissie van o-aandelen mogelijk te maken tot, bijvoorbeeld, $70 \%$ van het totaal geplaatst kapitaal. Indien bij de berekening van het aantal geplatste aandelen met stemrecht de aandelen, waarop het stemrecht door de vennootschap wordt gecontroleerd, buiten beschouwing zouden worden gelaten, zou een optimaal functionerende algemene vergadering zeker tot de mogelijkheden behoren. Bij beoordeling van de vraag of aandelen met stemrecht door van de vennootschap onafhankelijke (rechts-) personen worden gehouden, zou een regeling gehanteerd kunnen worden die vergelijkbaar is met de onafhankelijkheidscriteria die in Bijlage X van het Fondsenreglement door de Vereniging voor de Effectenhandel worden aangelegd. Hoe over de omvang van de mogelijke emissie van o-aandelen ook geoordeeld moge worden, aantrekkelijk lijkt de suggestie van Van der Grinten $^{45}$ te volgen en de o-aandelen aan toonder te doen luiden, terwijl de met zeggensmacht uitgeruste aandelen op naam worden gesteld. Nadeel hiervan is dat eenvoudige verhandeling van laatstbedoelde aandelen wordt bemoeilijkt en beursnotering van deze aandelen niet mogelijk is. Gezien de aard van de participatie in aandelen met stemrecht zal de eenvoudige verhandelbaarheid van deze aandelen echter niet central staan. Dit element is immers vooral voor de aandeelhouder/belegger van belang. Deze feiten overziend, lijkt het scheppen van de mogelijkheid meer o-aandelen dan gewone aandelen uit te geven, ondersteund te kunnen worden. Daarnaast biedt het op naam stellen van deze aandelen het voordeel dat een verdere beperking

44. Vigl. G. Noordraven, Macijerbundel (Van vennootschappelijk belang", 1988 , p. 182 .

45. T.a.p. noot 15. 
van de vrije overdraagbaarheid door middel van blokkeringsregelingen tot de mogelijkheden behoort. Zodanige blokkeringsregeling - dan vooral een strakke aanbiedingsvariant - zou in deze constellatie een afdoende beschermend effect hebben en in principe ledere verdere beschermingsmaatregel overbodig maken. Overigens is een krachtige bescherming in die gevallen ook noodzakelijk. Indien een omvangrijk deel van het geplaatst kapitaal uit o-aandelen zou bestaan, zou een overnemer voor een relatief gering deel van de prijs die hij anders zou moeten betalen, beslissende zeggensmacht in de vennootschap kunnen verkrijgen.

In het kader van deze bescherming verdient een aanbiedingsblokkade de voorkeur boven een goedkeuringsblokkade. In het eerste geval zou een overname tegen de wens van de directie onmogel ijk zijn zolang één aandeel in handen zou zijn van een kapitaalkrachtige bevriende relatie. Immers, zelfs al zou in zo"n geval 99\% van de houders van de aandelen met stemrecht besluiten in te gaan op een vijandig bod, dan nog zou dit niet kunnen slagen. Alvorens tot een geldige levering van de aandelen aan de bieder te geraken, zouden de desbetreffende aandelen aan de mede-aandeelhouders moeten worden aangeboden en heeft de vertrouwensrelatie de mogelijkheid te reflecteren. ${ }^{46}$ In een zodanige situatie, waarin een overgrote meerderheid vóór de overneming is, zal de neiging groot zijn de vertrouwensaandeelhouder uit te schakelen door wijziging van de statuten in die zin dat de aanbiedingsblokkade voor een goedkeuringsblokkade wordt verruild. Indien zodanige statutenwijziging met het enig doel zou plaatsgrijpen om de rechten van de mede-aandeelhouder te frustreren, lijkt mij dit besluit aantastbaar. Er zou mijns inziens sprake zijn van misbruik van meerderheidsmacht, hetgeen dit besluit rijp voor vernietiging maakt, en wel op basis van art. 2:11 BW als zijnde genomen in strijd met de goede trouw. ${ }^{47}$

Risico's in deze sfeer kunnen worden voorkomen door de statutaire bepaling dat wijziging van de regeling van de aanbiedingsblokkade in de statuten uitgesloten is. In dat geval zou de statutaire blokkeringsre-

46. De vraag voor welke prijs de aandeelhouder de hem in het kader van de blokkering angeboden aandelen zall kunnen verk rijgen, is interessant. Indien een regelling overeenkonstig art. 2: 195 BW zou worden gecrezerd, zouden onathankelijke deskund igen de watarde with de aangeboden aandelen moeten bepalen. Twijfelachtig lijkt mij dat bij die waardebepaling de hoogte van de geboden overname premie zal worden betrokken. Nu de omvang van die premie mede wordt bepaald door de kansen die de overnemer in de vennootschap ziet liggen, lijkt niet aannemelijk dat deze overname-premie in volle omvang door deskundigen zal worden meegenomen.

47. Anders Hof Leeuwarden, 28 juni 1989, Rolnr. 4786/88 (Lampe-Tonnema). Zie ook P.). Dortmond, De NV 67/9(1989), p. 184. 
geling uitsluitend gewijzigd kunnen worden met algemene stemmen in een vergadering waarin het gehele kapitaal is vertegenwoordigd. $O_{p}$ deze wijze zou de beschermingsconstructie perfect en onaantastbaar zijn. Immers, ook de uitkoopregeling zou hier, gezien het bepaalde in art. 2:92a lid $1 \mathrm{BW}$, geen uitkomst kunnen bieden. Overbodig te zeggen dat ook het eventueell gebruik van de geschillenregeling, gezien haar beperkte toepassingsgebied, onmogelijk is. ${ }^{48}$

Hierbij wordt ervan uitgegaan dat, bij emissie van aandelen met stemrecht, het voorkeursrecht van art. 2:96a BW slechts geldt voor houders van aandelen van deze soort. Zoals opgemerkt zou in mijn visie aan houders van o-aandelen bij emissie van aandelen van welke soort dan ook, geen voorkeursrecht toekomen. Aanpassing van het huidig art. 2.96a BW zou noodzakelijk zijn. In het kader van de bescherming van de vennootschap kan worden opgemerkt dat, in verband met lid 6 van dit artikel, zich hier een probleem kan voordoen, wanneer een meerderheid van de zittende aandeelhouders op de hand van een derde/potentieel overnemer is. Immers, die meerderheid zou kunnen besluiten in het kader van emissie van een fors pakket aandelen met stemrecht het voorkeursrecht uit te sluiten en plaatsing bij die derde te bewerkstelligen. Dit gevaar zou bestreden kunnen worden door zware eisen te stellen in het kader van het nemen van besluiten in deze sfeer. Overigens lijkt het hier geschetste geval zich uitsluitend in de angstdromen van de directie af te kunnen spelen.

Introductie van o-aandellen zou ook in het licht van het streven naar bescherming van vennootschappen een oplossing kunnen bieden. Zoals bekend leiden de thans gehanteerde beschermingsconstructies nog geregeld tot discussies omtrent de rechtsgeldigheid daarvan. Van het gebruik van 0-aandelen kan een krachtig beschermend effect uitgaan ${ }^{49}$, terwijl de rechtsgeldigheid daarvan na invoering in Boek $2 \mathrm{BW}$, niet meer ter discussie zal staan. Bijkomend voordeel zou zijn dat de regelgeving van de Vereniging voor de Effectenhandel aanzienlijk vereenvoudigd zou kunnen worden. De vraag of, bij gebruikmaking van o-aandelen, hantering van andere beschermingsconstructies toegestaan moet worden, laat ik hier rusten.

In mijn visie zouden derhalve de aandẻlen op naam stemrecht hebben, terwijl een gelijk - of zelfs een hoger - bedrag aan o-aandelen aan

48. Vgl. art. 2:335 lid $2 \mathrm{BW}$.

49. Vgl, de situatie bij het Duitse Nixdorf, waar de meerder heid van aandelen met stemrecht, tot de recente gewenste overname door Siemens, in handen was van twee stichtingen terwijl $^{2}$ de rest wan de aandelen (zonder stemrecht) ter beurze is genothend. FD 10/11/1989, p. 3 . 
toonder uitgegeven kan worden. Alleen deze o-aandelen zouden ter beurze kunnen noteren.

De suggestie van Van der Grinten ${ }^{50}$ volgend zou het register, waarin de rechten met betrekking tot geplaatste aandelen op naam zijn geregistreerd, openbaar kunnen zijn. Afgezien van hel feit dat zodanige openbaarheid dwingt tot zorgvuldige administratie zijdens het bestuur, brengt dit het voordeel met zilch dat (potentiële) o-aandeelhouders zich op de hoogte kunnen stellen van het feit wie zeggensmacht binnen de algemene vergadering toekomt.

Tenslotte de kwestie van een, verboden, emissie van o-aandelen doordat zodanige aandelen tot een hoger bedrag worden geplaatst dan zou zijn toegestaan. Globaal zouden hier twee wijzen van aanpak mogelijk zijn. De eerste is dat zodanige emissie nietig is, nu in strijd wordt gehandeld met een wettelijke bevoegdheid van het emitterend orgaan. De plaatsing van o-aandelen zal dan, wanneer de bovengrens wordt overschreden, eveneens nietig zijn. ${ }^{51}$ Ik houd niet zo van aantastbare besluiten en daarop gebaseerde handelingen, zeker niet waar het uitgifte van aandelen betreft.

Een andere aanpak lijkt te prefereren. Voorstelbaar is, bij overschrijding van de bovengrens van o-aandelen, stemrecht aan alle aandelen te verbinden, in die zin dat o-aandeelhouders op daartoe strekkend verzoek zeggensmacht in de algemene vergadering wordt. toegekend. Op die manier zal de vennootschap, naar mag worden aangenomen, snel actie nemen en overgaan tot emissie van aandelen met stemrecht. $\mathrm{Na}$ het herstellen van de voorgeschreven verhouding tussen 0 -aandelen en aandelen met stemrecht, zou dan het stemrecht op o-aandelen dienen te vervallen.

11. Bij emissie van o-aandelen zou een bijzondere categorie aandelen gecreèerd worden in de zin van art. 2:99 lid 2 BW. Zoals bekend

50. Van der Grinten, t.a.p. noot 15, P. $303 / 304$.

51. Probleem bij deze benadering zou nog zijn de vraag welke nieuw geplatatste andelen door zodarige nietigheid zouden worden getroffen. Nu het hiver zal gaan om toonderaan delen, is het de vraag of individualisering van de verschillende aandelen, wet als doel te bepalen welke aandelen wel rechtsgeldig zouden zijn geplaatst en welke niet, tot de mogelijkheden zou behoren.

Vgl. Hof Amsterdam, 20 mei 1986, NJ 1987, 733. 
verschaft zullks, althans wanneer dit statutair is bepaald, de mogelijkheid over te gaan tot intrekking van aandelen onder terugbetaling van het gestort kapitaal.

Het statutair scheppen van deze mogelijktheid bijo-aandelen zou het karakter van financieringsinstrument pur sang benadrukken. Daarnaast zal zodanige intrekking niet behoeven te leiden tot grote bezwaren van de zijde van de houders van de intrekbare aandelen. $\mathrm{Zij}$ zijn belegger en ontvangen, bij intrekking, hun inleg retour.

Wel kan de vraag gesteld worden of, gezien de directe betrokkenheid van de belangen van o-aandeelhouders byj het door de algemene vergadering te nemen besluit, die aandeelhouders in het kader van de besluitvorming hieromtrent stemrecht zou moeten toekomen. Gezien het puur financieel karakter van de deelneming en gezien het feit dat intrekking slechts met terugbetaling van gestort kapitaal kan plaatsvinden, meen ik deze vraag ontkennend te moeten beantwoorden.

Dat intrekking van o-aandelen, vanuit het perspectief van de vennootschap, op een bepaald moment gewenst zou kunnen zijn, is voor de hand liggend. Probleem in het kader van deze aangelegenheid is echter dat, ingevolge art. 2:99 BW, zodanige intrekking alle aandelen van die bepaalde soort moet betreffen. In zijn algemeenheid lijkt deze mogelijkheid van intrekking dan ook slechts theoretisch aanwezig.

De variant die genoemd artikel biedt is in dit verband aantrekkelijker. Mogelijk is statutair te bepalen dat de o-aandelen kunnen worden uitgeloot met terugbetaling. Deze regeling schept de mogelijkheid een situatie te creëren, waarin het de algemene vergadering op zeker moment vrijstaat tot uitloting van o-aandellen te besluiten, waarbij het uit te loten percentage o-aandelen statutair vrij kan worden bepaald.

In lid 5 van genoemd artikel wordt bepaald dat, indien er verschillende soorten aandelen zijn, voor een besluit tot kapitaalvermindering een voorafgaand of gelijktijdig goedkeurend besluit dient te worden genomen door de groep van aandeelhouders van een bepaalde soort. aan wier rechten afbreuk wordt gedaan. Duidelijk is dat, indien men met mij van mening is dat 0 -aandeelhouders in het kader van een besluit tot kapitaalvermindering geen stemrecht toekomt, er in voorkomende gevallen sprake zou moeten zijn van een voorafgaand goedkeurend besluit. $^{5.2}$

52. Terwijde merk ik op dat bijzodanig besluit mijns inziens niet per definitie sprake dient te zijn van het voldoen aan quorumeis of versterkte meerderheid. De vergadering van aandechhouders van een bepalde soort vormt een zelfstandig orgaan, warvan de leden veelal $\rightarrow$ 
Ik meen echter dat er bij intrekking van o-aandelen, of dit nu via loting of anderszins geschiedt, in het algemeen geen sprake zal zijn van het doen van afbreuk aan de rechten van o-aandeelhouders. Zoals opgemerkt wloeit dit voort uit de aard van de participatie, terwijl men op het moment van het verkrijgen van aandelen wist dat de mogelijkheid van intrekking aanwezig was. Wellicht is er noodzaak deze visie te nuanceren in die gevallen waarin aan de o-aandelen stemrecht is verbonden.

Afgezien van een uitgifte boven het toegestaan maximum (zie punt 10 hiervoor) zou dit stemrecht in mijn visie slechts aanwezig zijn wanneer de vennootschap achter loopt met voldoening van haar minimum-cumulatief preferente dividendverplichtingen. In die situatie echter, waarin de resultaten van de vennootschap slecht zijn, lijkt een o-aandeelhouder als belegger nog het meest gebaat bij intrekking van zijn aandelen met terugbetaling van het ingelegd vermogen. Toch kan in deze situatie, wellicht afhankelijk van het toekomstperspectief van de vennootschap, wel degelijk sprake zjjn van afbreuk van rechten door de intrekking. Immers, op het moment van intrekking verdwijnt de band tussen o-aandeelhouder en vennootschap. Naar moet worden aangenomen vervalt hiermede ook de latente claim op de vennootschap tot uitbetaling van het gecumuleerd dividend, welke invordering eerst mogelijk zou zijn indien de vennootschap op enig moment voldoende resultaat boekt.

In deze gevallen, dus waarin sprake is van een dividendclaim, in welke situatie er in mijn voorstel ook stemrecht aan het o-aandeel verbonden is, c.q. op verzoek van de aandeelhouder kan zijn, is er wel degelijk sprake van financiële rechten waaraan door de intrekking afbreuk wordt gedaan. In deze gevallen zou ik dan ook willen concluderen tot het vereiste van een voorafgaand of eventueel gelijktijdig goedkeurend besluit van de vergadering van o-aandeelhouders. Dit goedkeurend besluit wordt dan gegeven in het kader van het door de algemene vergadering te nemen besluit tot intrekking of tot uitloting van o-atandelen.

- tewens deel zullen uitmaken van de algemene vergadering. Bijo-aandeelhouders zou dat in mijn visie overigens niet het geval zijin. Ik meen derhalve dat de woor de besluitworming door de algemene vergadering gestelde eisen niet zonder meer van toepassing ziln op de besluitvorming binnen dit organ. Vergelijk wok de regeling wan art. 98 lid 2 wan het Voorstel Statuut voor de Europese Vennootschap, waar een wersterkte merderheidsregeling zoals die geldt bij besluitvorming door de algemene vergadering, van overeenthomstige toepassing wordt verklaard op afzonderlijke stemmingen binnen vergaderingen van houders van aandelew van een bepalde categorie. 
O-aandelen zijn stemrechtloze aandelen. Waar de kapitaalregeling in het kader van de inkoop van eigen aandelen door de vennootschap minder ziet op het zeggensmacht aspect, doch vooral uitgaat van de bescherming van het vennootschappelijk kapitaal, meen ik dat de wettelijke regeling met betrekking tot de begrenzing van de mogelijkheid van inkoop van eigen aandelen, onverkort op het te creerren o-aandeel toepassing dient te vinden.

12. Tenstotte wil ik in dit kort bestek, wat overigens een noodzakelijk lapidaire behandeling van deze materie tengevolge heeft, aandacht besteden aan de positie van de o-aandeelhouders in geval van ontbinding van de vennootschap.

Zoals hiervoor werd opgemerkt worden, bij ontbinding, belangen van de o-aandeelhouder bedreigd wanneer een onvoldoende uitkering voor aandeelhouders van alle categorieën uit het liquidatiesaldo te verwachten is. Indien dit niet het geval is zal, vanuit financieel perspectief, geen bezwaar tegen de ontbinding zijn aan te voeren. De o-aandeelhouder deelt gelijk op met alle andere aandeelhouders en kan eventueel een extra uitkering boven het door hem ingelegde kapitaal tegemoet zien.

Neteliger is de situatie indien bij de vereffening een tekort blijkt en niet iedere aandeelhouder aan zijn trekken kan komen.

De vraag is dan of er redenen zijn aan te voeren de o-aandeelhouder, bij de verdeling van het saldo na ontbinding, zwaardere aanspraken toe te kennen dan de andere aandeelhouders.

Argument tegen zodanige preferente aanspraak op een eventueel liquidatiesaldo zou kunnen zijn dat de o-aandeelhouder nu eenmaal risicodragend belegt en niet als een soort geldlener kan worden beschouwd, terwijl de vergadering van o-aandeelhouders in deze situatie in het kader van het ontbindingsbesluit een veto toekomt.

Hij heeft, als houder van preferent winstdelende aandelen, in de gloriedagen van de vennootschap de vruchten van zijn participatie geplukt. Gesteld kan worden dat extra vergoeding voor het ontbreken van zeggensmacht hem vooral werd toegekend in verband met het zwaardere risico-aspect dat a an zijn deelneming zonder zeggensmacht verbonden was. Naast het preferent dividend heeft hij voor het overige gelijk opgedeeld met andere aandeelhouders.

In deze visie lijkt het niet voor de hand te liggen een preferente 
aanspraak op het saldo bij liquidatie te scheppen. Mocht overigens blijken dat het ontzeggen van zodanige aanspraken leidt tot desinteresse in deze participatievorm bij de belegger, dan staat het de individuele vennootschap in mijn visie vrij statutair, in verhouding tot houders van gewone aandelen, voor de o-aandeelhouders zwaardere aanspraken te creëren.

Een andere visie is denkbaar. Hierin zou de vergelijking tussen de positie van o-aandeelhouders en geldschieter zwaarder benadrukt kunnen worden en zou gesteld kunnen worden dat het ontbreken van enige invloed op het vennootschappelijk beleid gecompenseerd zou moeten worden met niet alleen een aanspraak op cumulatief preferent dividend naast de normale winstdeling, maar ook met een preferente aanspraak op het saldo bij ontbinding.

Mijns inziens zijn weinig gronden aan te voeren op basis waarvan de o-aandeelhouder per definitie een zwaardere aanspraak op het saldo na ontbinding zou moeten toekomen. In mijn visie zal de o-aandeelhouder bij ontbinding een volstrekt gelijke positie als de gewone aandeelhouder innemen. In het hier voorgestelde systeem zouden de financiële rechten van de o-aandeelhouder mijns inziens voldoende gewaarborgd zijn.

13. Ik kom tot een afronding. In het voorafgaande worden, dat realiseer ik mij, meer vragen opgeworpen dan beantwoord. Ik heb getracht de grove contouren te schetsen van een mogelijke introductie van aandelen zonder stemrecht in ons nationale recht. Naar ik hoop word t op deze wijze een bruikbare inbreng geleverd in de discussies die rond dit thema plaatsvinden of nog plaats zullen vinden.

\section{Waarde boehoorders,}

Aan het einde van deze beschouwingen, moge ik vooreerst het College van Bestuur van de Rijksuniversiteit Limburg danken voor mijn be* noeming in deze functie. Het uit deze benoeming blijkend vertrouwen zal ik naar beste kunnen trachten waar te maken. 
Mijnher de decaan en owerige leden van de wetenschappelijke staf van de Faculteit der Rechtsgeteerdheid,

De tijd reeds in Uw midden doorgebracht, heeft mij geleerd dat het een voorrecht is aan $U w$ faculteit te mogen werken. De voortreffelijke collegiale contacten binnen de sectie Handels-en Ondernemingsrecht, maar ook daarbuiten, en de stimulerende sfeer die in Uw geledingen heerst, maken het werken hier tot een feest. Het is zoals ik mij dat in het zuiden had woorgesteld. Veel dynamiek en productiviteit, met op gepaste tijden aandacht voor de inwendige mens.

\section{Waarde Van Mourik,}

Ik kan mijgeen leukere plaats voorstellen als deze om $U$, als leerling, toe te mogen spreken. Ik bewaar aan al onze contacten de beste herinneringen. Als student in het notarièle recht te Leiden, had ik het voorrecht van Uw boeiende en stimulerende colleges te mogen genieten. Later, toen de promotie-arbeid een aanvang had genomen, bent $\mathrm{U}$ het steeds geweest die mij, met overigens gevierde teugel, leidde. Het enige nadeel aan het afronden van het proefschrift was, dat zo een einde kwam aan onze regelmatige werkbesprekingen in Restaurant de Doelen, welke gelegenheid ik steeds onder invloed van, onder meer, Uw wetenschappelijke denkbeelden mocht verlaten.

Hoewel een ieder in het leven een eigen stijl ontwikkelt, was en blijft. $\mathrm{U}$ voor mij, zowel op het terrein van onderwijs als onderzoek, een lichtend voorbeeld.

\section{Dames en Heren studenten,}

Het handels- en ondernemingsrecht mag zich binnen deze instelling in een zeer grote belangstelling Uwerzijds verheugen. Dit stemt mij tot vreugde en is overigens volstrekt terecht. Zonder nu direct mijn collegae een verkeerde keuze in de schoenen te willen schuiven, meen ik dat geen ander rechtsgebied zo dynamisch en maatschappelijk relevant is. Ik verheug mij er op $U$ in dit rechtsgebied te mogen inleiden en met $U$, binnen de facultaire gebouwen of in andere daartoe geëigende gelegenheden, over deze materie van gedachten te mogen wisselen.

Ik heb gezegd. 